\title{
Atitudes e crenças relacionadas ao sucesso em diferentes gerações: perspectivas intergeracional e intercultural
}

\author{
Behavior and beliefs related to success in different \\ generations: intergenerational and intercultural perspectives
}

\section{Comportamiento y creencias relacionadas con el éxito en las diferentes generaciones: perspectivas intergeneracionales e interculturales}

\author{
Renata Borja ${ }^{1}$ \\ ORCID: 0000-0002-4486-587X \\ Maria Natália Ramos ${ }^{2}$ \\ ORCID: 0000-0002-8448-1846
}

Resumo: $O$ presente estudo investigou o significado pessoal de bem-sucedido e as prioridades envolvidas na avaliação do referido termo, assim como as crenças e os comportamentos individuais de autoconceito, autoestima, capacidade, otimismo, pessimismo, preocupações, perfeccionismo, hábitos de organização, planejamento e capacidade de distribuição do tempo. Para a realização desta pesquisa, foi então elaborado um questionário online, disponibilizado nas redes sociais, do qual participaram 291 pessoas (brasileiros e portugueses), que responderam a questões relativas ao tema sucesso. Os significados socialmente partilhados no senso comum, associados à excelência, à perfeição, ao sucesso econômico, à fama e ao poder, não se mostraram compatíveis com os significados outorgados pela maior parte dos participantes da pesquisa, frequentemente associados ao equilíbrio entre vida pessoal e profissional, à felicidade, ao bem-estar, à família, à realização pessoal, à qualidade de vida e ao sentido da vida. Constatou-se, dessa maneira, a necessidade de uma ressignificação do termo, na tentativa de contribuir para o bem-estar social e psicológico, pois é possível que essa dissonância entre os significados esteja contribuindo com uma alta incidência de crenças incapacitantes relacionadas ao fracasso, observadas na prática clínica e educacional, principalmente entre jovens, o que pode ser um dos motivos do aumento da incidência dos transtornos psicológicos nos últimos anos.

Palavras-chave: Sucesso. Representações. Gerações. Crenças. Comportamento.

Abstract: This study has investigated the personal meaning of success and the priorities involved with the term, as well as individual beliefs and behaviors of self-concept, self-esteem, ability, optimism, pessimism, concerns, perfectionism, organizational habits, planning and time management. This research was carried out with 291 respondents (Brazilians and Portuguese), who freely decided to participate in an online survey shared on social networks. The common sense of the socially shared meanings of success, such as excellence, perfection, economic success, fame and power were not compatible with the meanings provided by most of the research participants. The majority associated the meaning with balance between personal and professional life, happiness, well-being, family, personal fulfillment, quality of life and the meaning of life. We have verified that this dissonance between meanings may be contributing to a high incidence of disabling beliefs related to failure. This has proven to be especially true among the youngest, as observed in clinical practice. Additionally, it could explain the reasons for the increased incidence of psychological disorders in recent years. In

\footnotetext{
${ }^{1}$ Universidade Aberta, Lisboa, Portugal. E-mail: renataborja.psico@hotmail.com

${ }^{2}$ Universidade Aberta \& CEMRI, Lisboa, Portugal. E-mail: Maria.Ramos@uab.pt
} 
Atitudes e crenças relacionadas ao sucesso em diferentes gerações...

order to contribute to social and psychological well-being, we have recognized the need for a resignification of the term.

Key words: Success. Representations. Generations. Beliefs. Behavior.

Resumen: Este estudio investigó el significado personal del éxito y las prioridades que implica la evaluación del término, así como las creencias y conductas individuales de autoconcepto, autoestima, capacidad, optimismo, pesimismo, preocupaciones, perfeccionismo, hábitos organizativos, planificación y asignación de tiempo. Para la realización de esta encuesta se preparó un cuestionario online, disponible en las redes sociales, donde participaron 291 personas (brasileñas y portuguesas) que respondieron a las preguntas sobre el éxito. Los significados socialmente compartidos en sentido común asociados con la excelencia, la perfección, el éxito económico, la fama y el poder no eran compatibles con los significados dados por la mayoría de los participantes en la investigación, que a menudo se asociaban con el equilibrio entre la vida personal y profesional, la felicidad, el bienestar, la familia, la realización personal, la calidad y el significado de la vida. Así pues, se señaló la necesidad de resignificar el término para tratar de contribuir al bienestar social y psicológico, ya que se considera posible que esta disonancia entre los significados pueda estar contribuyendo a una alta incidencia de creencias incapacitantes relacionadas con el fracaso, observadas en la práctica clínica, especialmente entre los más jóvenes, lo que puede ser una de las razones del aumento de la incidencia de trastornos psicológicos en los últimos años.

Palabras clave: Éxito. Representaciones. Generaciones. Creencias. Comportamiento.

\section{INTRODUÇÃO}

O mundo globalizado em que vivemos tem ampliado a mobilidade e o contato das pessoas entre diferentes regiões e países, o que vem estimulando processos e trocas interculturais dinâmicas, bem como a difusão de comportamentos, crenças e valores de uma cultura para outra, independentemente do contato pessoal ou virtual, atingindo, assim, pessoas situadas em locais geograficamente distantes do centro difusor.

Nesse contexto, não é incomum que países de maior poder econômico se tornem exemplo para países menos desenvolvidos e, talvez por isso, a noção de sucesso, em vigor na cultura norte-americana, tenha se espalhado por quase todo 0 globo. A adoção dessa noção, em outros contextos culturais, entre os quais se incluem Brasil e Portugal, adquire, dessa maneira, novos contornos e significações, já que está submetida à influência de crenças e valores diversos dos vigentes na cultura norte-americana. Um dos pontos centrais da noção norte-americana de sucesso tem sido a valorização dada às pessoas que obtêm sucesso (winners) e a depreciação das que não o obtêm, os fracassados (losers). Diante disso, os estudos sobre a cultura e a interculturalidade tornam-se importantes, como alternativa para se compreender melhor essas influências e relações e suas consequências (RAMOS, 2013).

A importação e a adoção de um novo conceito, de forma rígida e generalizada, podem gerar prejuízos morais e sociais dentro de uma sociedade e, 
sob essas condições, o conflito torna-se inevitável. Para Henessy (1985), citado por Wakefield (1996), é natural que exista uma tensão entre a vontade de mudança e a vontade de se manter como está, quando novos valores externos são introduzidos numa sociedade. Assim, quando o significado do bem-sucedido atinge culturas diferentes daquela que deu esse sentido ao termo, é possível que se instaure, inicialmente, algum mal-estar social e individual, principalmente se esse significado confrontar crenças e valores da cultura que o importou. A compreensão e o estudo da inserção de um novo conceito e seus impactos positivos e negativos precisam ser analisados no contexto social para se verificar a necessidade uma nova proposta educacional. Um hábito ou uma crença tornam-se institucionalizados quando passam a ser culturalmente compartilhados, mesmo que a sua origem seja proveniente de outra cultura. Quando isso acontece, é natural que esse novo comportamento exiba um funcionamento diferente de seu funcionamento na cultura original. Isso significa que se leva algum tempo até que se processe a acomodação de um conceito, uma vez que é preciso uma adaptação à nova realidade. Para Piaget (1964/1999, apud DIAS; COLOMBO; MORAIS, 2019), a construção do conhecimento ocorre pela ação de uma pessoa sobre o meio que vive, ou seja, as ideias se constroem num processo de interação e troca entre sujeito e objeto de conhecimento.

Somente com a reversão cultural, mediada pela educação, seja possível, mudar o modus operandi e conseguir atingir uma missão mais elevada do desenvolvimento humano, que não seja por questões das necessidades básicas dos indivíduos, é nesse cenário, que ocorre os esforços no âmbito da educação e do trabalho. (SILVA; VIEIRA, 2019).

O significado de sucesso, proveniente do contexto cultural norte-americano, amplamente difundido pela mídia no meio empresarial e esportivo, é aquele que consegue levar sua empresa ou seu grupo a sobrepor-se aos concorrentes e a situar-se entre os melhores de sua área, o que lhe confere poder, prestígio e boas condições financeiras. No âmbito escolar, a ideia de sucesso já se refere a resultados como boas notas, boas avaliações e destaque acadêmico. O que há em comum, nessas atribuições conferidas ao ser bem-sucedido, não é necessariamente a noção americana de vencedor e perdedor, mas a aquisição de bons resultados, na consecução das metas socialmente valorizadas como primordiais nessas áreas.

As atitudes e as crenças relacionadas ao sucesso, na contemporaneidade, estão longe de ser unânimes. A adoção de um conceito de sucesso que busca o 
Atitudes e crenças relacionadas ao sucesso em diferentes gerações...

destaque, a excelência e quase a perfeição, por exemplo, pode estar contribuindo para o aumento da ansiedade, do estresse e da depressão em alguns indivíduos, uma vez que esses objetivos são ultradimensionados e até mesmo irrealistas para a grande maioria, podendo influenciar, negativamente, a visão pessoal e o comportamento diante de projetos de futuro.

No nosso estudo e na análise das representações do sucesso na pesquisa bibliográfica, assim como nos resultados da pesquisa empírica, foi observado que o significado do termo e suas crenças e ideias subjacentes sofreram várias alterações com o decorrer dos anos, dentro de uma mesma cultura e de uma cultura para outra. A compreensão das implicações positivas e negativas da representação social do sucesso na atualidade e a proposta de uma educação para valores torna-se essencial para o aprofundamento da sua relação com a saúde mental e física e com a qualidade de vida e bem-estar.

\section{RELEVÂNCIA DO ESTUDO}

\subsection{A modificação do perfil do bem-sucedido na mídia e sua relação com o bem-estar}

A análise feita por Ituassu (2012) das reportagens da Exame (principal publicação do ramo de negócios no Brasil), no período de 1971 e 1998, encontrou diferenças no "perfil do bem-sucedido" traçado pela revista, ou seja: nos anos 70, o bem-sucedido se apresentava como um "homem empreendedor e ambicioso, branco, magro e bem aparentado, maduro"; enquanto nos anos 90, o bem-sucedido era descrito como "jovem que tem alto cargo, bom salário e empregabilidade, mas vida social conturbada" (ITUASSU, 2012, p. 8).

Esse exemplo já demonstra uma mudança no perfil, no comportamento e no bem-estar daqueles "considerados bem-sucedidos". O primeiro perfil observado é apresentado como mais saudável que o segundo, sugerindo um aumento do malestar relacionado ao termo, de uma geração à outra, comprovado pela elevação exponencial de casos de depressão e de ansiedade nos dias atuais. Aventou-se a hipótese de essa alteração do "perfil do bem-sucedido" ser uma consequência das mudanças sociais ocorridas em grande parte por estímulo do marketing e da mídia, principalmente por meio da supervalorização da juventude, o que por sua vez 
influenciam o ciclo natural das relações intergeracionais. Entretanto, não se pode esquecer que essa influência atinge todas as gerações, sendo o impacto diferente de acordo com o grupo a que pertencem e com as representações sociais partilhadas por cada grupo.

Outro ponto relevante constantemente destacado na mídia se relaciona com os termos sucesso e fracasso, valorizando cada dia mais a eficácia, a competência e o resultado e reprovando o fracasso, assim como no conceito original de loser e winner. Segundo Ituassu (2012), vários autores têm apontado a mídia como um dos fatores responsáveis por uma cultura de gestão, que difunde e legitima o "culto à excelência". Apesar das diferenças culturais, o conceito de sucesso norte-americano (loser - winner), já internacionalizado, tem sido amplamente reforçado graças à divulgação de filmes que promovem a difusão dos valores da cultura americana aos quatro cantos do mundo.

A mídia tem servido quase como um reforçador de grandes sucessos e fracassos, das políticas públicas, da economia, da educação, dos esportes, das artes da saúde, o que acaba por contribuir para intensificar a ansiedade coletiva fundamentada na obrigação pelo sucesso e no medo do fracasso. Entretanto, dicotomicamente, na atualidade a mídia e as redes sociais também têm propagado e estimulado o sucesso de pessoas despreparadas, que não necessariamente fizeram algo exemplar e excelente, antes pelo contrário. Do lado oposto, não é incomum observar a dificuldade que alguns profissionais de excelência e mais experientes encontram em se expor às mídias sociais por receio de serem interpretados como charlatões. Esse sucesso "vazio" de conteúdo contribui para uma confusão mental e expectativas irrealistas, tornando ainda mais fracassado e psiquicamente vulnerável aquele que não consegue obter o dinheiro, a fama e o poder, apesar do esforço e do preparo.

\subsection{Representação coletiva do sucesso e significado individual}

Outro ponto relevante a ser investigado diz respeito à subjetividade da representação coletiva do sucesso, uma vez que a concepção de uma pessoa sobre o seu significado nem sempre é adotada por outra. No estudo feito por De Vries (2010) entre executivos, sobre esse significado, a maioria, em grande parte, 
Atitudes e crenças relacionadas ao sucesso em diferentes gerações...

considerada workaholic, cita a família como o maior marcador de sucesso e não o trabalho, o dinheiro e os altos cargos. O histórico disfuncional de suas famílias originais contribuiu com o desejo de oferecerem aos filhos uma realidade melhor. Por outro lado, muitos deles, apesar de serem considerados bem-sucedidos, na noção de sucesso externa demonstraram uma insatisfação pessoal com os êxitos profissionais obtidos, talvez por não conseguirem dedicar o tempo que gostariam ao seu marcador de sucesso: a família.

\subsection{O aumento crescente das doenças mentais}

Klerman (1970 apud Seligman, 2012, p. 100), por exemplo, "ao pesquisar a incidência de doenças mentais nos EUA, identificou um fator inesperado sobre a predominância, maior ou menor, de depressão, no decorrer da vida". A expectativa era que se encontrasse, nas pessoas mais velhas, uma quantidade maior de episódios depressivos, uma vez que elas tinham vivido por um período mais longo. Todavia, a pesquisa demonstrou que, quanto mais velhas eram as pessoas, menor era o número de episódios depressivos por elas vivenciados. Com efeito, pessoas nascidas antes da primeira guerra, no início do século $X X$, apresentaram $1 \%$ de episódios depressivos ao longo da vida, enquanto as pessoas nascidas no terço médio do século XX (que seriam, portanto, mais novas) apresentavam dez vezes mais possibilidades de ter episódios depressivos.

Trazendo a incidência da depressão para os dias atuais, esses dados tornamse mais preocupantes, pois como destaca a Organização Mundial de Saúde a depressão tem vindo a aumentar no mundo. Entre 2005 e 2015, o número de casos de depressão aumentou 18\% (WHO, 2017). Também de acordo com a pesquisa feita por Gilham et al. (1996 apud Seligman, 2012, p. 20), a percentagem de crianças com sintomas ansiosos é alarmante, variando entre $20 \%$ e $45 \%$. Essa crescente incidência de depressão e ansiedade, assim como de transtornos psicológicos com o passar do tempo, faz-nos refletir sobre as diferentes crenças geracionais sobre si, os valores e o sucesso. Identificar e destacar os elementos mais valorizados, nas diferentes gerações, e associá-los aos estudos sobre incidência de depressão poderá contribuir, pois, para uma melhor compreensão do 
modo como esses elementos mais valorizados e as crenças e os comportamentos que Ihes são subjacentes podem ajudar ou dificultar o bem-estar de cada geração.

\subsection{O sucesso, o bem-sucedido e suas modificações ao longo da história}

A noção de sucesso, presente no senso comum, é amplamente utilizada em diversos setores da sociedade, mas os impactos das crenças e dos significados individuais associados não são muito estudados e pesquisados. A maioria dos estudos trata o sucesso como se ele tivesse apenas um significado implícito, excluindo-se, assim, as mudanças ocorridas no significado do termo ao longo da história global e nas diferentes fases de vida das pessoas.

A ideia de "sucesso" com o sentido de feitos extraordinários que resultam em dinheiro, fama e poder, de forma mais generalizada, está presente em diversas áreas e culturas ao longo da história, embora suas formas e contornos possam ser diferentes. Na Grécia antiga, ele estava relacionado com a vitória competitiva de cunho religioso e mítico e a superação de obstáculos e limites associadas. Até mesmo em culturas mesoamericanas, o sucesso no esporte era evidenciado, pois há relatos de reverenciamento aos atletas, assim como de possibilidade e mobilidade social e recebimento de vantagens em função do destaque gerado pelo excelente desempenho (RUBIO, 2001; TOOHEY \& VEAL, 2007). Rubio (2001) relaciona o atleta contemporâneo ao mito do herói, e é exatamente essa associação que contribui com os altos salários recebidos por esportistas de mais destaque midiático. A morte de um atleta-herói que tem amplo destaque internacional gera comoção nacional, pois ela representa a perda de uma superioridade. Um fato importante de se ressaltar é que na Grécia antiga, para que um atleta fosse reconhecido e reverenciado por suas vitórias, não era apenas necessário que ele atingisse grandes resultados, ele precisava também ser reconhecido como um bom cidadão, evidenciando a importância de valores éticos e culturais.

Assim como na Grécia antiga, a base da ideia de sucesso norte-americano vinculada à ideia de self-made-man, ressaltada e estimulada por Benjamin Franklin ainda no século XVII, estava vinculada à religiosidade e à ética. Segundo Weber (1967), a concepção de self-made-man está construída dentro da ética protestante que associa o sucesso ao trabalho duro, esforço, autodisciplina e capacidade de 
Atitudes e crenças relacionadas ao sucesso em diferentes gerações...

autossacrifício, à predestinação e salvação. Portanto, a "falta de vontade de trabalhar é um sintoma da ausência do estado de graça" (WEBER, 1967, p. 113). De acordo com Weber (1967), nessa ética protestante, o enriquecimento não era o objetivo em si, mas um sinal e um caminho para a salvação. Tornar-se rico era um dever moral e uma obrigação com Deus e essa riqueza não deveria ser utilizada para os prazeres da carne, mas para economizar e aumentar o capital com novos investimentos. Os primórdios do capitalismo, segundo esse autor, não estão fundamentados no orgulho e no egoísmo. Por isso, deveria ser estimulado para o "bem da nação", até mesmo porque estava fundamentado em valores morais e éticos, assim como pontualidade, laboriosidade e honestidade. Mas houve tão grandes modificações na representação social do sucesso, que não é incomum hoje se associar o sucesso a condutas antiéticas e amorais.

Essa noção de sucesso associada à espiritualidade e aos valores já não se mantém, até mesmo nos EUA, antes pelo contrário. O sucesso de uma empresa é medido na atualidade, principalmente, pela capacidade dessa de gerar riqueza. $O$ objetivo óbvio das empresas é o lucro e, para que isso aconteça, é preciso ter profissionais capazes e motivados no seu quadro de empregados. Ferrage (2012) explica que uma organização eficiente depende da motivação gerada por boas lideranças. Não é raro, portanto, o estímulo ao sucesso, como sinônimo de dinheiro e reconhecimento, numa tentativa de motivar, de forma extrínseca, os dirigentes e os empregados de uma empresa. Esse dinheiro propiciaria prazeres consumistas, o que se diferencia muito da noção original.

As possíveis consequências negativas desse estímulo são questionadas por Callanan (2003), que acredita que essa prática pode incentivar condutas antiéticas por parte dos empregados. Para esse pesquisador, a obtenção do sucesso de forma ilícita torna-se nociva à empresa e ao empregado. Essa falta de ética, como recurso para o sucesso, ajuda a compreender um dos motivos que contribuem para a associação da ideia de bem-sucedido a uma pessoa desequilibrada e desajustada, como foi observado na pesquisa de Ituassu (2012). Esse significado, em grande parte das vezes, estimula empresas e empregados a valorizarem a competitividade desenfreada, o estresse, a falta de tempo para vida pessoal e a falta de ética para se atingir objetivos rentáveis (CALLANAN, 2003; ITUASSU, 2012; ITUASSU e TONELLI, 2012). 
Esse modelo, apesar de questionável, ainda se faz muito presente na atualidade, sendo fonte de muita angústia e frustração para muitos. O problema, que faz esse esquema se manter, talvez resida num hábito reforçado pela crença equivocada que compreende a vantagem financeira como uma meta compartilhada pelos jovens no início de carreira.

\subsection{A representação social do sucesso na atualidade e problemas relacionados}

No âmbito empresarial, escolar e esportivo, as ideias associadas à representação social do sucesso referem-se, na maioria das vezes, a um excelente desempenho, com ótimos resultados. No meio acadêmico isso está ligado a boas notas e, no meio esportivo, diretamente, à ideia de vitória, voltada para a competição e a superação de obstáculos e de limites. Enquanto no meio empresarial, está relacionado com o lucro e os altos cargos.

Segundo Berger e Luckman (1985 apud Ituassu e Tonelli, 2012, p. 13), o sucesso assumiu preponderantemente um significado "de vida de posses, altas posições, bons salários e prestígio" (idem), tornando-se sinônimo disso. Tal significado acabou por se institucionalizar, tornando-se padrão e influenciando as pessoas, sem que elas tivessem consciência.

Pode-se constatar, assim, que as publicações feitas pela mídia reforçam e incentivam as pessoas a perseguirem o sucesso, como se este, por si só, já representasse uma fonte de prazer, satisfação e felicidade. Parece existir uma propaganda subliminar para o sucesso que associa o enriquecimento, a fama, os altos cargos, o prestígio e o poder à felicidade. É como se a mídia gritasse diariamente: "Quer ser feliz? Então faça algo para ser famoso e conquiste dinheiro e poder!".

A ideia de felicidade equivalente a sucesso, entretanto, não se confirma, conforme exposto por Tanure, Carvalho, Neto e Andrade (2007 apud Ituassu e Tonelli, 2012), que revelam a insatisfação e a infelicidade de indivíduos classificados como bem-sucedidos. Para esses indivíduos o desprazer estava aliado à falta de equilíbrio na distribuição do tempo, em consequência de uma necessidade de reconhecimento social, o que gerava um excesso de trabalho. Do mesmo modo que 
Atitudes e crenças relacionadas ao sucesso em diferentes gerações...

pessoas "bem-sucedidas" podem sofrer por não terem o equilíbrio desejado, outras sofrem por não se julgarem capazes de atingir padrões de "sucesso" esperado.

Problemas psicológicos associados a esse significado têm sido descritos. Kuiper (1978), por exemplo, faz uma associação entre os estilos de atribuição ao sucesso e ao fracasso com a depressão. Segundo esse autor, pessoas não depressivas se sentem mais responsáveis pelos seus sucessos do que pelos seus fracassos, enquanto somente os depressivos entendem que o fracasso está associado a causas internas provocadas por eles mesmos.

\subsection{A necessidade de ressignificação do sucesso e algumas propostas}

Ituassu e Tonelli (2012) lembram que o sentido "institucionalizado" de sucesso relacionado ao poder, fama e dinheiro, por ter sido construído coletivamente, seria passível de uma reconstrução, uma vez que esse significado tem apresentado consequências problemáticas para a vida das pessoas. Nesse mesmo caminho de ressignificação, Pahl (1997), para quem o modelo de sucesso econômico competitivo e agressivo estaria com os dias contados, propõe um novo modelo mais flexível e mais "feminino", baseado no equilíbrio e na capacidade de se relacionar. 0 mal estar produzido por um significado de sucesso vazio de significado, valores e sentido já tem começado a ser questionado inclusive no meio empresarial e vários movimentos já tem sido iniciado numa tentativa de reeducação do empresariado mostrando as vantagens de novas propostas embasadas na ética, na reciprocidade, nos valores e sentido. A "economia de comunhão" e o "capitalismo consciente" são exemplos desse movimento.

Sturges (1996) também discute os diferentes significados de sucesso em "What it means to succeed: Personal conceptions of career success held by male and female managers at different ages". De acordo com a pesquisadora, o sucesso externo compreende a ideia de sucesso convencional, ligada a dinheiro, a cargos e ao poder. O sucesso interno compreenderia ideias pessoais de valor. O sucesso abstrato (intangible) se relacionaria com uma ideia de reconhecimento e respeitabilidade. Para a autora, o sucesso mais "tradicional", incentivado pela maior parte das empresas, já não se sustenta, pois não corresponde às expectativas de todos. Para ela, devido a não existência de um conceito homogêneo de sucesso, 
seria necessário legitimar as novas percepções e reforçá-las, no contexto empresarial, a fim de que elas possam continuar motivando e recompensando seus funcionários, adequadamente.

Outras mudanças de significado também foram observadas por Gerolimatos e Worthing (1999). Essas pesquisadoras estudaram as definições do sucesso, dadas por uma maioria de mulheres bem-sucedidas ligadas a áreas da academia, indústria, governo, representantes de organizações e fundações, em dois momentos. Elas observaram que a definição de sucesso, citada pelas participantes da conferência da New York Academy of Sciences em 1972, estava relacionada ao reconhecimento pelos próprios pares da profissão. Entretanto, 25 anos depois, numa conferência intitulada Women and Success: Anatomy of Achievement, a definição estava relacionada à ideia de vida pessoal e profissional equilibrada, em que o trabalho possibilite autonomia, controle, poder de escolha e possibilidade de lutar pelos próprios objetivos. Nesse segundo momento, um dos grupos de trabalho fez uma observação relevante: "Encontrar nossa identidade é mais importante do que definir o sucesso, especialmente por padrões estabelecidos por homens ou pela instituição" (GEROLIMATOS e WORTHING, 1999, p. 1352). Existe, portanto, nesse estudo, a valorização do significado pessoal dado ao termo, o que demonstra certa resistência ao significado mais difundido, já que ele não se aplica a todos e parece não interessar à maioria das pessoas. Outro ponto importante dessa mesma pesquisa diz respeito ao fato de que "as medidas tradicionais de sucesso" não foram muito relatadas, pois poucas definições se referiam ao poder, a altos cargos e a altos salários. Nessa nova discussão, uma grande mudança de pensamento foi percebida, uma vez que o reconhecimento foi visto como uma recompensa extra e não mais como o essencial, para se considerar bem-sucedido. Nesse segundo momento, 0 grupo de mulheres mais velhas considerou como valor uma liderança que pudesse impactar e promover mudanças na vida das outras pessoas, o que demonstra que o essencial passou a ser um sentido voltado a um bem-estar comum, fundamentado numa capacidade de fazer diferença na existência das pessoas.

A dificuldade de se delimitar o significado do termo sucesso pode estar contribuindo para a existência, em determinadas circunstâncias, de certo mal-estar social. Abele e Spurk (2009), ao estudarem a percepção da carreira de sucesso, sob uma ótica objetiva (aquela avaliada pela sociedade por meio da posição hierárquica) 
Atitudes e crenças relacionadas ao sucesso em diferentes gerações...

e subjetiva (aquela que considera a avaliação individual sobre si), puderam constatar que os profissionais com tendência a fazer uma avaliação subjetiva positiva de sucesso acabavam indo de encontro ao sucesso mais objetivo. Eles sugerem, por conseguinte, que as empresas deveriam prestar mais atenção à ideia de sucesso subjetivo, em vez de estimular apenas o sucesso objetivo por meio de premiações e recompensas salariais.

Outro fator importante que merece ser ressaltado se refere ao fato de que a noção de sucesso não se mantém a mesma em diferentes fases da vida. As prioridades pessoais vão se modificando com o tempo, assim como objetivos e metas. Um fator relevante observado no estudo de Gerolimatos e Worthing (1999), confirmado na pesquisa de Sturges (1996), foi a percepção de que a definição individual de sucesso pode mudar, com o decorrer do tempo. Isso significa que, num primeiro momento, o foco pode ser a vida profissional, depois, esse foco pode passar para a vida familiar e, num outro momento, migrar para um sentido maior.

\subsection{As representações sociais do sucesso e sua conexão com o bem-estar psicológico}

O mundo atual está cada dia mais conectado, aberto e intercultural, devido aos avanços tecnológicos, à facilidade de meios de transporte e de deslocamento, ao surgimento da internet e de toda a rede de comunicação que ela propicia, principalmente por meio das mídias sociais, e ao aumento da mobilidade humana e da globalização (RAMOS, 2013, 2016). É nesse contexto conectado e tecnológico que se estudam as representações sociais do sucesso, tendo em conta as perspectivas intercultural, geracional e de gênero.

Para compreender melhor os resultados desta pesquisa, é necessário citar Moscovici (2017), que ultrapassa a dicotomia entre as representações individuais e as "coletivas", proposta por Durkheim. Em vez de tratá-las separadamente, atribuindo as representações individuais ao campo da psicologia e as representações coletivas à área da sociologia, Moscovici (2017) considera possível abarcar as duas perspectivas, uma vez que uma se propõe a descobrir novos fenômenos por meio da resposta a questões relacionadas a crenças e vínculos sociais e a outra se interessa em aprofundar-se na linguagem e na comunicação do pensamento presente no senso comum. 
As representações sociais, tais como Moscovici as concebe, propicia-nos uma melhor forma de compreender as construções sociais da realidade, suas motivações e seu funcionamento. Elas são essenciais, igualmente, para se investigarem as cognições presentes na vida cotidiana, tanto aquelas que expressam conteúdo socialmente partilhado, quanto as cognições individuais que podem vir a tornar-se compartilhadas. As representações sociais e a comunicação estão intimamente ligadas e são interdependentes. Conforme apresentado anteriormente, a representação social do sucesso vem sofrendo alterações nos seus significados, e a nossa pesquisa (MELLO, 2017), ao mesmo tempo em que demonstra uma aparente incompatibilidade entre os significados individuais e coletivos, torna possível perceber os significados individuais como uma reação a um incômodo com o significado partilhado, que vai se transformando por meio da expressão e da comunicação desses novos significados. A representação social do sucesso, apesar de ainda manter implicitamente a ideia de dinheiro, poder e status, demonstra grandes transformações relacionadas a valores associados, fazendo com que 0 termo seja associado a diferentes imagens de homem "bem-sucedido" no decorrer do tempo, como demonstrado na pesquisa de ITUASSU e TONELLI (2012).

O exemplo dado acima nos ajuda a compreender que representações sociais são também fenômenos de mutação contínua, uma vez que os significados dados a determinado objeto são construídos na interação constante do indivíduo com o mundo. Assim, os diversos significados de sucesso individuais coletados interferirão na mutação do significado coletivo. O estudo desses fenômenos de mutação ajudanos a compreender melhor os processos cognitivos individuais e sociais e as interações sociais.

O interesse de Moscovici pelas representações sociais é: "Estudo de como, e por que, as pessoas partilham o conhecimento e desse modo constituem sua realidade comum, de como elas transformam ideias em prática" (MOSCOVICl, apud DUVEEN, p. 8). É importante ressaltar que essa "realidade", apresentada pelas representações sociais não constitui, pois, uma reprodução fidedigna do objeto, mas uma construção reforçada cognitivamente por meio de evidências que induz ao equívoco de compreendê-la como realidade. Para Arruda (2002), essa realidade é uma versão de outra que está em contínua transformação, assim como o objeto. 
Atitudes e crenças relacionadas ao sucesso em diferentes gerações...

Pode-se dizer, portanto, que as representações sociais abarcam pensamentos, crenças e interpretações da realidade, provenientes do contexto sociocultural, afetivo, econômico, educacional, ideológico e científico, exprimindo uma confluência de todas essas influências.

Outro ponto que merece destaque tem relação com as duas funções das representações sociais apresentadas por Moscovici (2017). Convencionalizar objetos significa classificá-los de forma a criar um modelo distinto e facilmente identificável a ser partilhado. A função prescritiva é aquela presente, implicitamente, é aquela força que determina o que devemos pensar. É o não dito que deve ser seguido.

As representações sobre o sucesso enquadram-se perfeitamente nisso, uma vez que o conceito do termo já é facilmente identificável, apesar de as pessoas não pensarem, especificamente, sobre dinheiro, poder e status, mas se comportarem em função deles, mesmo não tendo plena consciência do que estão fazendo e para que estão fazendo. E é exatamente esse comportamento automático que nos interessa nesta pesquisa.

A importância dos elementos afetivos na elaboração das representações sociais é ressaltada por Jodelet, ao afirmar que:

\begin{abstract}
As representações sociais devem ser estudadas articulando-se elementos afetivos, mentais e sociais e integrando-os ao lado da cognição, da linguagem e da comunicação - a consideração das relações sociais que afetam as representações e a realidade material, social e ideativa sobre a qual elas têm de intervir. (JODELET, 2001, p. 26).
\end{abstract}

Nesse ponto, as abordagens cognitivo-comportamental, a racional-emotiva e a abordagem metacognitiva têm muito que colaborar, pois elas aprofundam as relações entre as cognições e emoções e reconhecem e reforçam a especificidade da cognição- emoção-comportamento, num círculo que se reforça. Essas abordagens consideram que as emoções exercem um papel muito relevante na confirmação das cognições, pois geralmente por meio da experiência emocional é que as pessoas se apercebem das suas cognições. Essa emoção, por sua vez, pode produzir novos pensamentos, baseados na própria experiência emocional, como se essa experiência ativasse outra cognição, que reforça a experiência emocional, num círculo vicioso. Exemplo: Uma pessoa se preparou bastante para uma prova e teve um resultado aquém do esperado. E ela pensa: "Eu sou um fracasso mesmo!". Sente-se triste e, ao observar a sua emoção, pode concluir: "Não 
adianta, eu não tenho energia e nem disposição para conseguir meus objetivos!". Essa conclusão ajuda a tirar a pouca energia que restou para se persistir.

Beck, Rush, Shaw \& Emery (1997), no livro “Terapia Cognitiva da Depressão", explicam que o paciente deprimido entra num ciclo vicioso, em que os seus pensamentos negativos, disfuncionais, são reforçados por uma experiência emocional negativa (tristeza), que culmina num comportamento autoderrotista. Esses mesmos autores compreendem que muitos pacientes depressivos se veem incapacitados, em função da experiência emocional negativa. Isso significa que a experiência emocional propicia novas cognições com a ideia de incapacidade, que acabam gerando mais tristeza e reforçando comportamentos de esquiva, evitação, falta de ação, paralisia. Beck (1997) reconhece a importância de identificar as reações emocionais inadequadas, como forma de identificar as emoções associadas e as cognições disfuncionais.

Essa compreensão sobre a importância da experiência emocional e de como essa experiência pode acabar reforçando o "esquema" ajuda-nos a compreender melhor, também, as representações sociais. Com esse intuito, é bom levar em conta a colocação de Wells de que:

O estado emocional é determinado pelo status do sistema com relação ao
alcance de seus objetivos. Em geral, a ansiedade está associada à
antecipação do fracasso em atingir os objetivos, enquanto a depressão está
associada a um fracasso existente. (WELLS, 2001, p. 21).

A constatação de que a ideia de fracasso está por trás do sofrimento mental faz com que se torne urgente a compreensão do sucesso e de seus significados, já que o fracasso é uma realidade que todos experimentam, em algum momento da vida. Essa transformação bilateral do sujeito pelo objeto (sucesso) e do objeto (sucesso) pelo sujeito demonstra uma capacidade de adaptação que reforça o propósito de tornar algo incômodo em algo familiar (MOSCOVICI, 2017).

Muitas publicações acadêmicas e midiáticas recentes já têm relacionado o "sucesso", e não apenas o fracasso, a uma ideia de sofrimento, talvez devido às consequências negativas observadas pelos excessos praticados em prol da busca do sucesso, em seu sentido tradicional/ institucionalizado, pela falta de equilíbrio e ética nessa busca ou até mesmo por muitas vezes o sucesso "externo" não ser capaz de se associar à felicidade. Em uma pesquisa feita por Borges e Casado baseada na análise de filmes, o executivo de sucesso aparece como: "Alguém com problemas para se adaptar às exigências da profissão, que toma decisões com base 
Atitudes e crenças relacionadas ao sucesso em diferentes gerações...

em valores questionáveis, busca reconhecimento a qualquer custo e é incapaz de realizar trabalhos emocionais" (BORGES e CASADO, 2009 apud ITUASSU e TONELLI, 2012, p. 208).

De acordo com Beck, Rush, Shaw \& Emery (1997), existe uma tríade cognitiva que consiste em três diferentes tipos de cognição: sobre si, sobre o mundo e sobre o futuro. Os pensamentos sobre si refletem uma tendência do sujeito de se autoavaliar, de acordo com seu padrão interno de crenças. Os pensamentos sobre o mundo referem-se à forma como ele interpreta o ambiente e a sua relação com as pessoas a sua volta. Os pensamentos sobre o futuro, por sua vez, refletem a expectativa do sujeito sobre o futuro e sobre projeções de longo prazo. Cabe reforçar que, quando os pensamentos sobre o futuro são interpretados como ameaça, a experiência de medo se faz presente. Beck (1996) lembra que a pessoa deprimida tem uma tendência a se interpretar como derrotada ou fracassada, no sentido de ser incapaz de atingir suas próprias metas e realizações, e por isso, interpretar o mundo como hostil e o futuro como fonte de frustração e privação. Muitos dos pensamentos do deprimido se relacionam, portanto, com a ideia de fracasso. O medo do fracasso é tão grande, que a pessoa deprimida foca continuamente nessa sensação, que acaba por se reforçar, ao passo em que ela evita agir e o fracasso se verifica por falta de ação. Essa mesma lógica serve para a "obrigação" com a felicidade: quanto mais alguém se cobra sentir-se feliz e se observa sem as sensações positivas que compreende que deveria sentir, menos feliz ela se sentirá.

Nossa prática clínica permitiu-nos observar diariamente os significados atribuídos a situações semelhantes, por pessoas diferentes. Nessas observações, foram percebidas muitas diferenças em relação aos pensamentos de jovens, adultos e idosos e suas atribuições relativas ao sucesso e ao fracasso. Beck também se interessou pelo estudo da relevância do sucesso-fracasso na autoestima (SALKOVSKIS, 2005). Os resultados obtidos por Beck mostraram que os deprimidos por ele estudados reagiam bem ao obter bons resultados com suas ações, o que demonstrava que essas pessoas se tornavam deprimidas exatamente por exibirem uma tendência em tentar evitar o fracasso, exatamente, por valorizarem excessivamente a experiência de sucesso. E essa estratégia de fuga das suas próprias crenças disfuncionais é que resultava numa maior experiência de fracasso, 
completando o círculo negativo (SALKOVSKIS, 2005). Compreendendo que a noção de pequenos "sucessos diários" é que constrói a ideia de sucesso mais ampla, torna-se indispensável compreendermos melhor o sentido do termo também no campo social. Esse estudo deixa claro que o deprimido apresenta uma cobrança pelo resultado positivo, ao mesmo tempo em que compreende haver uma falta de recursos para atingi-lo, o que reforça o seu estado.

O tratamento dado, neste trabalho, à representação do sucesso se assemelha ao tratamento dado por Jodelet em "Loucura e Representações Sociais":

\begin{abstract}
As representações como uma forma de pensamento social, cuja gênese, propriedades e funções devem ser relacionadas com os processos que afetam a vida e a comunicação sociais, com os mecanismos que concorrem para a definição da identidade e a especificidades dos sujeitos sociais, indivíduos ou grupos, assim como a energética que está na origem das relações que esses grupos mantêm entre si. Para pôr em ação tal perspectiva, unindo as abordagens psicológicas e sociais, é preciso que nos interessemos por contextos sociais reais e adotemos um ponto de vista pluridisciplinar. (JODELET, 2005, p. 50).
\end{abstract}

\title{
3 METODOLOGIA E RESULTADOS
}

Com o objetivo de identificar e compreender representações e crenças relacionadas com o significado de sucesso, foi desenvolvida uma pesquisa de caráter exploratório. Utilizamos inquérito por questionário, constituído por questões abertas e fechadas, e recorremos à utilização de métodos de análise qualitativa e quantitativa. Além de dados sociodemográficos (sexo, idade, gênero, tipo de trabalho, escolaridade, salário, religiosidade), o questionário coletou informações sobre o significado do conceito de sucesso, além de obter informações sobre autoconceito, preocupações, ansiedade, organização e perfeccionismo.

O presente inquérito foi disponibilizado nas redes sociais, principalmente por meio de e-mail, Facebook e WhatsApp. Optamos por utilizar uma ferramenta de software para questionários, disponível online, que nos ajudou na divulgação e na análise de dados. $\mathrm{O}$ objetivo da pesquisa online era atingir um público diverso e deixar o participante mais autônomo para responder ao questionário.

Obtivemos 291 questionários completamente preenchidos, tendo recebido igualmente mais de 150 questionários incompletos que, por isso, foram excluídos. Sobre os participantes e em relação ao sexo, tivemos 79 homens $(27,05 \%)$ e 212 mulheres (72,60\%). Desse total, tivemos a adesão de: 21 (7,22 \%) de jovens com 
Atitudes e crenças relacionadas ao sucesso em diferentes gerações...

idade entre 18 e 25 anos; 60 (20,62\%) de jovens entre 26 e 35 anos; 83 (28,5\%) de adultos de 36 a 45 anos; 71 (24,40\%) de adultos de 46 a 55 anos; $28(9,62 \%)$ de adultos de 56 a 65 anos; e $28(9,62 \%)$ de idosos acima de 66 anos.

A escolaridade dos participantes foi muito acima da média brasileira, pois, segundo os dados fornecidos pelo IBGE (2015), 30,7\% da população brasileira tem entre 11 e 14 anos de estudo, apenas 13\% tem mais de 15 anos, verificando-se que mais de $57 \%$ da população tem no máximo o ensino fundamental completo. $\mathrm{Na}$ nossa pesquisa, entretanto, 30,24\% tinham curso superior completo e $36,77 \%$ tinham especialização, $12,02 \%$ tinham mestrado, 2,41\% doutorado, 1,72\% pósdoutorado, ou seja, $83,16 \%$ dos pesquisados tinham no mínimo curso superior completo.

Apesar da alta escolaridade dos respondentes, a pesquisa teve uma amostra bem variada no quesito ganho salarial. De acordo com a nossa amostra: 15,46\% ganham até 2 salários mínimos; 15,80\%, de 2 a 4 salários; 7,56\%, de 4 a 6 salários; $6,87 \%$, de 6 a 8 salários; $17,5 \%$, de 8 a 15 salários; $13,06 \%$, mais de 15 salários; $8,5 \%$ dos participantes optaram por não fornecer essa informação; $1,03 \%$ disseram não saber; e $14,09 \%$ disseram que essa pergunta não se aplicava a eles. Provavelmente, nesses últimos três grupos incluem-se os $7,22 \%$ de participantes que estão desempregados e que não possuem ocupação ou trabalho.

Foram realizados dois tipos de análise no que se refere ao significado de bem-sucedido. A primeira, de cariz qualitativa, foi feita a partir das respostas dadas às perguntas: "O que significa para você ser bem-sucedido?"; "Você se considera bem-sucedido? Se sim, porquê?”; “O que para você significa não ser bemsucedido?". A segunda foi feita avaliando de forma quantitativa os resultados à questão: "Enumere por ordem de prioridade o que é importante para que você possa se considerar bem-sucedido?". Essa questão tinha nove alternativas para serem enumeradas por prioridade: poder, dinheiro, reconhecimento/fama, relacionamentos e amizades, família, fazer algo que tenha significado/sentido, realização pessoal, superação, trabalho. 


\subsection{Significados de sucesso encontrados na pesquisa}

Do primeiro tipo de análise das respostas sobre os significados de sucesso, foram destacadas as seguintes categorias: autoeficácia; estar bem; ajudar o próximo/cidadania; conhecimento; dignidade; dinheiro; espiritualidade; família; felicidade/prazer; metas pessoais; poder/fama; realização pessoal; realização profissional; reconhecimento; relacionamentos; saúde; sentido; ser realista; tempo; trabalho; valores; superação.

Nessa análise, a categoria felicidade/prazer foi a mais referida de forma espontânea, o que representa uma tendência de as pessoas relacionarem a ideia de sucesso com o prazer e a felicidade. Na segunda categoria aparece o trabalho, apontando que o sucesso está fortemente relacionado à função laboral. A família surge em terceiro lugar. Em quarto lugar situa-se a categoria realização pessoal.

Analisando essas respostas espontâneas e as categorias citadas, observamos três grupos de significado para o sucesso dados pelos participantes.

No primeiro grupo, "afetividade/estar bem", encontramos 101 respondentes, o que equivale a $34,71 \%$ do total da pesquisa que relacionava o significado de sucesso a boas relações familiares e sociais, boas emoções e sensações como felicidade, bem-estar, bons comportamentos sociais, como cidadania e ajuda ao próximo, valores, espiritualidade, fazer algo que tenha sentido e significado. Esse grupo refere-se, principalmente, a sensações e conexões. Os valores desse grupo assemelham-se muito ao constructo de personalidade sociotrópica descrito por Beck e que valoriza as relações e a dedicação ao próximo (CLARK \& STERR; BLACKBURN, in SALKOVSKIS, 2005).

Para o segundo grupo, "capacidade/desempenho", temos 100 respondentes $(34,36 \%)$ : o significado de sucesso relaciona-se à capacidade, ao desempenho, à independência, a metas, ao trabalho e a resultados. Nesse grupo valoriza-se a autoeficácia, a capacidade de conseguir altos rendimentos, a realização profissional e a capacidade de superação e de reconhecimento. Esse grupo refere-se sobretudo a ações e trabalho, assemelhando-se ao constructo de personalidade autônoma descrito por Beck (CLARK \& STERR in SALKOVSKIS, 2005; BLACKBURN, in SALKOVSKIS, 2005). 
Atitudes e crenças relacionadas ao sucesso em diferentes gerações...

O terceiro grupo, "equilíbrio", com 88 respondentes $(30,24 \%)$, apresenta componentes dos outros dois grupos e valoriza o equilíbrio das diversas áreas da vida, pessoal e profissional, e a boa utilização do tempo.

\subsection{Elementos relevantes para a autoatribuição de sucesso}

No segundo tipo de análise feita de forma quantitativa às respostas para a questão "Enumere por ordem de prioridade o que é importante para que você possa se considerar bem-sucedido?', os resultados evidenciaram que os respondentes consideraram como prioritário: a grande maioria $(61,17 \%)$ escolheu a família, como primeira opção; $13,40 \%$ priorizaram a realização pessoal; 10,65\%, fazer algo que tenha significado e sentido; 5,15\%, o poder; 3,09\%, o trabalho; $2,41 \%$, o reconhecimento/fama; 2,41\%, a superação; 1,03\%, o dinheiro; 0,69\%, o convívio social/amizades.

Nosso estudo, apesar de não ter se restringido aos executivos como no estudo de DeVries (2010) citado anteriormente, que identificou a família como um marcador de sucesso, também verificou que a família é o elemento primordial para a maioria dos entrevistados (61,7\%) se autoavaliarem como bem-sucedidos. Apesar de o "poder" ter ficado em quarto lugar, como a primeira opção dos entrevistados, ele aparece em último lugar, quando fazemos a classificação das prioridades em geral, pois, para a grande maioria dos pesquisados, ele foi escolhido como a opção de número 9 (58,08\%), o que parece divergir da representação de sucesso mais divulgada, que associa o termo a altos ganhos financeiros, prestígio, visibilidade e poder.

Para avaliarmos a classificação das prioridades, a partir do segundo lugar de classificação, optamos por somar a quantidade de pessoas do primeiro e segundo lugares e verificar qual foi o elemento escolhido pela maioria, por meio do número maior da soma. Optamos por destacar a soma na tabela como forma de contribuir para a compreensão da classificação. Os números 1 a 9 indicam o quanto cada item foi escolhido naquela ordem, pelos respondentes, e a ordem em que se encontram organizados os elementos apresenta a classificação da preferência geral da maioria dos respondentes da pesquisa. 
Quadro 1 - Ordem de prioridade para ser bem-sucedido (resultado geral)

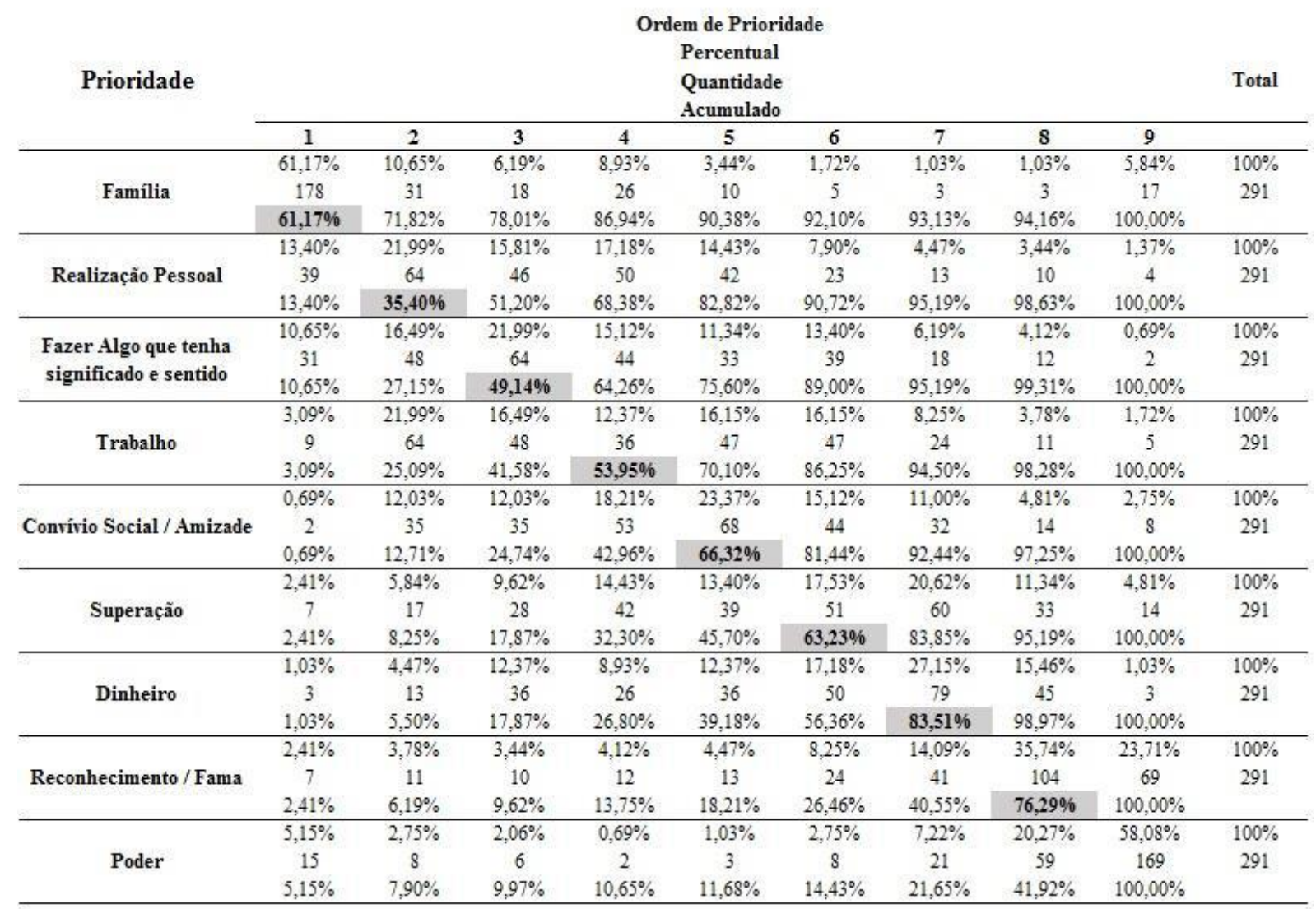

Fonte: autoras da pesquisa

Além do oposicionismo entre família e poder, outros resultados interessantes foram observados. Na classificação geral a realização pessoal aparece como a segunda mais valorizada, seguida por fazer algo que tenha significado e sentido que, por sua vez, apresentou a menor taxa de rejeição, já que foi o item menos citado no nono lugar. Essa ordem de prioridade pareceu-nos interessante, pois as ideias de realização pessoal e sentido são contrárias à ideia de reconhecimento/ fama ou poder.

Enquanto o reconhecimento e a fama estão voltados para uma avaliação externa de sucesso, feita por outros, e o poder está relacionado com a hierarquia e o comando de outros, a realização pessoal apresenta uma noção de conquista de valores internos e uma ideia de capacidade e de autoeficácia, o que seria uma espécie de autorreconhecimento pelo bom trabalho executado. Fazer algo que tenha sentido e significado também retorna o foco para si mesmo e para a capacidade de produzir algo importante e relevante que possa ter, na maioria das vezes, um impacto positivo na vida de outras pessoas ou para um bem maior. "Eu encontro 
Atitudes e crenças relacionadas ao sucesso em diferentes gerações...

alegria e significado na minha vida quando me engajo em um propósito mais profundo e conheço a mim mesmo" (PATTAKOS \& DUNDON, 2015, p. 109).

Viktor Frankl, psiquiatra austríaco, autor do livro "Em busca de sentido", que relata sua passagem por um campo de concentração na época da guerra, vivenciando uma situação extrema de estresse e sofrimento, reforça, a importância que o dar sentido ao que se faz tem para a sobrevivência e compreende que esse fator possibilita que as pessoas superem situações de extremo sofrimento de forma mais otimista e tranquila. Para ele, o sentido pode ser obtido pelo exercício da espiritualidade, pela dedicação a uma obra ou pelo amor e o cuidado com o próximo (FRANKL, 1989; 2007). A busca pelo sentido está muito associada à realização pessoal e vai na contramão da busca pelo reconhecimento ou fama social, pois não é o outro, a sociedade ou seus pares que as pessoas devem agradar para receber o reconhecimento, mas a elas mesmas e aos seus propósitos.

Essa modificação das crenças sobre o sucesso foi também apresentada na pesquisa de Gerolimatos e Worthing (1999) com mulheres, citada anteriormente, não sendo necessária, portanto, uma avaliação externa, mais abrangente, como forma de garantir, reforçar ou saber do seu próprio valor. O que importa aqui não é o que virá do outro, mas o impacto que a ação de um indivíduo pode gerar na vida de outros, e não o reconhecimento destes outros especificamente.

O item "trabalho" apareceu na quarta colocação da classificação e "convívio social e amizades", na quinta. Dos cinco primeiros elementos escolhidos pela maioria, três deles demonstram ter uma relação direta com a valorização da conexão com o outro, por meio dos elementos escolhidos: família, sentido, convívio social e amizades. Os outros dois elementos, a "realização pessoal" e o "trabalho", estão focados na capacidade de se perceber capaz e de ser produtivo, sendo também reforçados pela ideia de fazer algo que tenha sentido. A superação ficou em sexto, na frente de dinheiro, apesar de ambas apresentarem percentuais semelhantes. "Reconhecimento/ fama" e "poder" apareceram na oitava e nona colocação, respectivamente.

Esses resultados, referentes ao conceito individual e elementos relevantes para o significado, nos levam a perceber e avaliar que o sentido do sucesso já não se relaciona tanto com a medida externa de sucesso, bem pelo contrário. O sucesso está mais voltado para valores internos de satisfação pessoal e convívio com outros. 


\subsection{Flexibilização do significado}

Outro ponto interessante encontrado na pesquisa sugere a existência de uma flexibilização interna do significado mais tradicional do sucesso, uma vez que a maioria das pessoas se autoavaliou como bem-sucedida. Além disso, essa porcentagem apareceu alta até mesmo no grupo com os salários mais baixos, o que demonstra de certa forma que o significado relacionado ao enriquecimento não se mantém para todos. Atingir enriquecimento, fama e poder torna-se uma meta quase impossível para a grande maioria da população, portanto, uma flexibilização torna-se essencial para evitar a experiência de fracasso, infelicidade e sofrimento. Essa flexibilização identificada pode ser um indicativo do caminho da transformação da representação social.

Tabela 1 - Autoconceito sobre ser bem-sucedido autoavaliação de

\begin{tabular}{|c|c|c|}
\hline & & Total \\
\hline $\begin{array}{l}\text { VOCÊ SE CONSIDERA } \\
\text { BEM SUCEDIDO? }\end{array}$ & Respestas & 291 \\
\hline \multirow{2}{*}{ SMI } & $62,20 \%$ & $100,00 \%$ \\
\hline & 181 & 291 \\
\hline \multirow{2}{*}{ ANDANío } & $11,00 \%$ & 100,0096 \\
\hline & 32 & 291 \\
\hline \multirow{2}{*}{ EMPARTE } & $13,06 \%$ & 100,0096 \\
\hline & 38 & 291 \\
\hline \multirow{2}{*}{ Nĩo } & $12,37 \%$ & $100,00 \%$ \\
\hline & 36 & 291 \\
\hline \multirow{2}{*}{ NÃO DESEJO RESPONDER } & $1,37 \%$ & 100,0096 \\
\hline & 4 & 291 \\
\hline
\end{tabular}

Tabela 2 - Intensidade da bem-sucedido

Fonte: autoras da pesquisa

Nas respostas para a afirmação "Sou uma pessoa bem-sucedida", se fizermos a soma do se aplica, se aplica muito e se aplica totalmente, encontraremos um total de $74,22 \%$ que praticamente coincidem com a soma do bem-sucedido e bem-sucedido em parte, da pergunta "Você se considera bem-sucedido?", o que totaliza em $75,26 \%$. As diferentes respostas nos dão algumas pistas interessantes. Dado o fato de, na pergunta aberta (Tabela 1), 62,20\% se considerarem bemsucedidos, mas apenas 7,56\% responderem se aplica totalmente e $20,27 \%$ dizerem que se aplica muito, a intensidade do bem-sucedido pode indicar resquícios da noção de sucesso mais tradicional nessa autoavaliação, isso porque, talvez, para se considerarem muito ou totalmente bem-sucedidos, eles ainda estejam presos a alguma característica da noção de sucesso externa. Por outro lado, o fato de apenas 36 pessoas $(12,3 \%)$ do total não se considerarem bem-sucedidas, no conjunto dos 
Atitudes e crenças relacionadas ao sucesso em diferentes gerações...

291 participantes, demonstra uma certa flexibilidade na autoatribuição para o termo, o que, por outro lado, é confirmado quando apenas 4,4\% responderam não se aplica para o sucesso.

Tabela 3 - Sucesso X Salário

\begin{tabular}{|c|c|c|c|c|c|c|}
\hline & \multicolumn{6}{|c|}{ Bem Sucedido } \\
\hline & TOTAL & SIM & NÃo & EM PARTE & AINDA NÃO & $\begin{array}{c}\text { SEM } \\
\text { RESPOSTA }\end{array}$ \\
\hline \multirow{2}{*}{ Até 2 salários mínimos } & \multirow{2}{*}{45} & 22 & 7 & 6 & 9 & 1 \\
\hline & & $48,89 \%$ & $15,56 \%$ & $13,33 \%$ & $20,00 \%$ & $2,22 \%$ \\
\hline \multirow{2}{*}{ De 2 a 4 salários mínimos } & \multirow{2}{*}{46} & 29 & 4 & 5 & 7 & 1 \\
\hline & & $63,04 \%$ & $8,70 \%$ & $10,87 \%$ & $15,22 \%$ & $2,17 \%$ \\
\hline \multirow{2}{*}{ De 4 a 6 salários mínimos } & \multirow{2}{*}{22} & 15 & 3 & 3 & 1 & 0 \\
\hline & & $68,18 \%$ & $13,64 \%$ & $13,64 \%$ & $4,55 \%$ & $0,00 \%$ \\
\hline \multirow{2}{*}{ De 6 a 8 salários minimos } & \multirow{2}{*}{20} & 13 & 4 & 2 & 0 & 1 \\
\hline & & $65,00 \%$ & $20,00 \%$ & $10,00 \%$ & $0,00 \%$ & $5,00 \%$ \\
\hline \multirow{2}{*}{ De 8 a 15 salários minimos } & \multirow{2}{*}{51} & 41 & 2 & 6 & 2 & 0 \\
\hline & & $80,39 \%$ & $3,92 \%$ & $11,76 \%$ & $3,92 \%$ & $0,00 \%$ \\
\hline \multirow{2}{*}{ Mais de 15 salários mínimo: } & \multirow{2}{*}{38} & 23 & 3 & 9 & 3 & 0 \\
\hline & & $60,53 \%$ & $7,89 \%$ & $23,68 \%$ & $7,89 \%$ & $0,00 \%$ \\
\hline \multirow{2}{*}{ Não se aplica } & \multirow{2}{*}{41} & 20 & 11 & 3 & 6 & 1 \\
\hline & & $48,78 \%$ & $26,83 \%$ & $7,32 \%$ & $14,63 \%$ & $2,44 \%$ \\
\hline \multirow{2}{*}{ Não sei } & \multirow{2}{*}{3} & 1 & 0 & 0 & 2 & 0 \\
\hline & & $33,33 \%$ & $0,00 \%$ & $0,00 \%$ & $66,67 \%$ & $0,00 \%$ \\
\hline \multirow{2}{*}{ Não desejo responder } & \multirow{2}{*}{25} & 17 & 2 & 4 & 2 & 0 \\
\hline & & $68,00 \%$ & $8,00 \%$ & $16,00 \%$ & $8,00 \%$ & $0,00 \%$ \\
\hline
\end{tabular}

Fonte: autoras da pesquisa

A atribuição de sucesso utilizando o enriquecimento como medida não foi validada (Tabela 3), visto que 48,99\% daqueles que ganhavam até 2 salários mínimos se consideraram bem-sucedidos. Observamos, haver, entretanto, uma certa relação entre o sucesso e o ganho financeiro, pois a quantidade de pessoas que se considerava "bem-sucedida", de acordo com a faixa salarial, cresceu progressivamente acompanhando o aumento do salário, atingindo 80,39\% (no grupo que recebia entre 8 e 15 salários mínimos). Entretanto, no grupo que recebia mais de 15 salários, vimos esse número de bem-sucedidos baixar para 60,53\%, apresentando uma porcentagem inferior, até mesmo comparativamente ao grupo de 2 a 4 salários. Podemos concluir, portanto, que ainda existe uma relação entre a ideia de sucesso e ganho financeiro, mas que não é possível fazer uma relação entre o sucesso e o enriquecimento. Esses dados contribuem para reforçar a existência de 
uma flexibilização do significado do sucesso como sinônimo de enriquecimento, fama e poder.

\section{DISCUSSÃO E CONCLUSÃO}

Nossa pesquisa contribuiu com dados para uma melhor compreensão da ambiguidade existente na apresentação do sucesso como um fim a ser perseguido vinculado à ideia de sensações positivas e, ao mesmo tempo, como um fim que pode trazer sofrimento. As crenças sociais que levam a uma automatização da busca de um sucesso imensurável e subjetivo pode ser uma das explicações para esse sofrimento. Observamos que a maioria dos nossos respondentes faz, de alguma forma, uma flexibilização do termo e por isso consegue se considerar bemsucedido mesmo não se encaixando na noção externa de sucesso. Entretanto, as crenças partilhadas socialmente poderão contribuir para o sofrimento daqueles que se mantiverem nessa ambiguidade. Compreendemos que a conexão com um significado individual e mais palpável de sucesso, baseado em metas pessoais fundamentadas em valores, propósito e sentido, poderia ser uma das soluções para esse problema.

Os resultados da pesquisa evidenciaram que o significado dado ao sucesso foi bem mais abrangente do que as noções mais divulgadas socialmente e/ou através dos meios midiáticos. Os resultados mostram que o sentido do sucesso já não se relaciona tanto com a medida externa/objetiva de sucesso, muito pelo contrário. Está mais voltado para ideias internas/subjetivas de satisfação pessoal e convívio com outros. Entretanto, esses resultados entram em conflito com alguns comportamentos observados na contemporaneidade, pois, ao mesmo tempo que as pessoas querem se conectar e criar vínculos, elas, ao invés de se ocuparem em agir em direção ao próximo, para que esse contato verdadeiramente aconteça, utilizamse das redes sociais, o que costuma gerar desconforto e desconexão, principalmente nas relações mais próximas. Parece haver uma automatização mental disfuncional gerada pelo reforço social da repetição do conceito externo/objetivo que explica o descompasso entre o que as pessoas valorizam e desejam verdadeiramente, e o modo como elas se comportam e os resultados que colhem com suas ações. 
Atitudes e crenças relacionadas ao sucesso em diferentes gerações...

Trazer à luz as modificações ocorridas na representação social do sucesso ao longo do tempo, pode ser de grande valia para a compreensão do conflito entre metas internas e externas relacionadas ao sucesso. O sucesso do self-made-man se fundamentava num enriquecimento, fama e poder desprovido e dissociado de prazeres mundanos. Ser bem-sucedido era associado a um propósito moral e espiritual relacionado a valores e estimulado e conduzido por uma ideia de "sucesso" como recompensa divina ancorada em atitudes responsáveis e morais.

$\mathrm{Na}$ década de 60 o sucesso ressurge vinculado à competição e aos conceitos de loser e winner, e os valores morais e éticos começam a ser substituídos pela vitória e pela superação de concorrentes. O dinheiro não é mais apenas um dos medidores de sucesso, mas começa a se apresentar também como uma recompensa. O ser humano tem uma necessidade de sentir-se recompensado, pelo que a recompensa divina explicitada por Weber (1967) é então substituída pela recompensa financeira. $O$ aumento das oportunidades financeiras, por meio do desenvolvimento associado à falta de um propósito maior, que estimule e recompense o autossacrifício, parece contribuir, por parte das empresas e da mídia, com o estímulo, nas décadas seguintes, à busca pelo enriquecimento como caminho para a felicidade. Entretanto, essa fórmula de sucesso financeiro associado à felicidade não se confirma e não são raros os relatos de "bem-sucedidos" que não se consideram felizes. Recentemente, a felicidade tem sido pesquisada e reforçada, não mais como um fim, mas como um caminho para o sucesso, inclusive no seu significado mais tradicional.

Essa pluralidade de significados, observada ao longo deste estudo, pode ser explicada pela possibilidade de o sucesso, em sua representação mais abrangente, ter um sentido ligado à realização e à consecução de metas e objetivos que possibilitem uma experiência de realização pessoal, o que explicaria, portanto, o elevado número de pessoas que se autoconsideraram bem-sucedidas na nossa pesquisa.

O sucesso adquire, assim, múltiplas significações individuais, já que os objetivos pessoais refletem valores individuais. Os três diferentes grupos de significado individual de sucesso encontrados nesta pesquisa (Mello, 2017) (1. afetividade/ estar bem: sensações e conexões; 2 . capacidade/desempenho: ações e trabalho; 3. equilíbrio: capacidade e estar bem) demonstram, por sua vez, um 
padrão ou uma tendência social. Isso explicaria porque alguns consideram sucesso ter dinheiro, enquanto outros consideram cuidar bem da família e outros, ainda, ser feliz. Os três grupos de significado encontrados apresentam a diversidade existente na representação social do sucesso e uma tendência à valorização de elementos anteriormente considerados como mais associados ao gênero feminino, como o cuidado, a sensibilidade e as conexões, como proposto por PAHL (1997).

Os significados de sucesso encontrados na nossa pesquisa coincidem com as hipóteses de Pahl, pois encontramos, nas respostas dadas, menções à felicidade, à família, ao bem-estar, aos relacionamentos, às amizades, ao equilíbrio, à qualidade de vida, ao amor, à ajuda ao próximo, à realização, ao fazer o que se gosta, ao fazer algo que tenha sentido e à saúde, além de outros significados. Entretanto, dos significados mais usuais, somente o dinheiro foi mais citado, mas na maioria das vezes, num sentido de condição financeira para se ter uma vida digna e não para o enriquecimento propriamente dito.

Uma das principais conclusões do estudo relaciona-se com o fato de que a grande maioria dos respondentes se considerou bem-sucedida, o que nos faz supor que foram capazes de valorizar mais o significado individual do termo e, por isso, apresentam-se mais flexíveis e saudáveis. Esse resultado pode demonstrar uma mudança natural na representação social do conceito que está mudando o significado de externo/objetivo, algo que possa ser mensurado externamente, para algo interno/subjetivo, baseado nos próprios valores, que é avaliado e validado pelo próprio sujeito.

A investigação demonstra que a representação social de sucesso, estimulada e reforçada pela sociedade e mídias, não se equivale ao conceito de sucesso individual. As metas de sucesso irrealistas para a maioria, impostas pela mídia, podem estar contribuindo para o aumento de ideias de fracasso, que por sua vez contribuem para o aumento de transtornos depressivos e ansiosos. A relação entre ideias de fracasso e o aumento progressivo dos sintomas depressivos e ansiosos tem sido observada em pesquisas recentes, como, por exemplo, a de Seligman (2011), que faz uma associação entre o fracasso e os transtornos emocionais, na seguinte constatação: "Os seres humanos vêm ficando seriamente deprimidos desde que se tem notícia do que seja fracasso". 
Atitudes e crenças relacionadas ao sucesso em diferentes gerações...

A delimitação do significado do conceito de sucesso tem se tornado mais complexa, devido às diferentes atribuições que the são outorgadas, em diversas áreas. Mas o fato é que, qualquer que seja a definição dada, pelas diferentes gerações, existe, frequentemente, em todas elas, um estresse, um sofrimento e uma cobrança em cumprir a meta proposta para a obtenção do sucesso.

O significado mais usual e amplamente difundido em todos os setores da sociedade está relacionado com a ideia de sucesso econômico, fama, poder e resultados de destaque. Mas muitos autores já têm começado a questionar esse significado por perceberem os danos causados por essas metas elevadas.

Seguimos um modelo de sucesso focado apenas no resultado, no conceito de loser (perdedor) [...] ser um loser é ser capturado e tapeado pelo marketing do consumo e ter seus valores, foco e energia vital aprisionados aos bens materiais como forma de status e sentido de vida. [...] Ser um loser é perseguir uma ilusão de felicidade que nunca se realiza, através da fama, dinheiro e do sucesso (COBRA JR, 2017, p. 12).

Esse mesmo autor, profissional da área esportiva, também questiona a promoção dos excessos, que tem contribuído para o aumento de diversas patologias, como bulimia, anorexia e vigorexia, que muitas vezes são impulsionadas pela mídia, ao estimular o consumismo, a competição, o narcisismo e o foco excessivo na performance: "Estimula-nos a sacrificar tudo, vender a própria alma em busca de dinheiro, sucesso e fama? A pergunta que não quer calar é: esta busca traz realmente felicidade?" (COBRA JR., 2017, p. 13).

A associação do sucesso à felicidade, apesar de demonstrar uma necessidade de ressignificação e uma busca das pessoas por algo mais significativo, também pode estar contribuindo para o mal-estar, pois existe outra grande dicotomia que envolve o significado de felicidade. Para Ben-Shahar (2018, p. 55), "o grande objetivo de todo esforço humano é a conquista da felicidade". Assim, o sucesso no sentido de metas alcançadas seria ser feliz. A ideia da felicidade como algo a ser conquistado pode ser equivocadamente interpretada, por muitos, como algo que deva acontecer no futuro como resultado de uma determinada ação, e não como uma sequência de escolhas e comportamentos que visem o viver plenamente o tempo presente com propósito e significado, como se esse presente já fosse uma recompensa. Para Ben-Shahar (2018, p. 56), "a pessoa feliz desfruta de emoções positivas e ao mesmo tempo vê significado em sua vida", noção de felicidade que seria o conceito ideal. Entretanto, no senso comum, é frequente confundir essa 
felicidade com o prazer imediato (hedônico), que não é capaz de manter emoções positivas por mais tempo.

Juntamente ao fato de se encontrar uma demanda, pela mudança do significado de bem-sucedido, para um significado mais funcional e saudável, há indícios de continuidade de incentivos a condutas antiéticas feitos pelas empresas, principalmente para os mais jovens, com promessas de sucesso, como sinônimo de riqueza, prazer e felicidade. Essas condutas, entretanto, podem tornar-se fonte de sofrimento futuro quando o objetivo de felicidade não for atingido. A substituição de um propósito maior, ligado a valores, pelo dinheiro e pelo prazer hedônico, focado apenas num prazer volúvel e imediato, parece ser o responsável pela inexistência da felicidade, mesmo quando se obtém o sucesso externo. A despeito de a proposta de capitalismo mais convencional, muitas vezes, contribuir para a desconexão dos indivíduos com sua essência e valores, a humanização das empresas, pautada na coerência, ética, partilha e propósito, já tem se apresentado uma possibilidade viável. O "capitalismo consciente", por exemplo, é um movimento originado num estudo conduzido por Raj Sisodia, Jaf Shereth e David Wolf que verificou que valores éticos aliados à responsabilidade, sustentabilidade e propósito eram capazes de fazer uma empresa ser lucrativa sem precisar gastar excessivamente com marketing e publicidade. Essa nova proposta de gestão demonstra que, além de o propósito de um bem maior social ser mais vantajoso e sustentável, apresenta, também uma solução eficaz no combate à insatisfação do modelo capitalista mais convencional, o que indica que o "sucesso" (externo) de uma empresa pode ser alcançado se fundamentado em valores internos dos seus gestores e não o contrário como vinha sendo feito por grandes corporações. (MACKEY \& SISODIA, 2018)

Um dos autores que questionam o sucesso e propõem uma ressignificação é Ray Pahl (1997), sociólogo e professor da Universidade de Kent, que assinala no seu livro "Depois do Sucesso: Ansiedade e Identidade Fin-de-Siècle": "Parece que muitas pessoas manifestamente bem-sucedidas costumam duvidar de si mesmas e indagar-se, no fundo, suas vidas não passam de um fracasso. Ora, não haverá aí uma visão social do sucesso que elas, intuitivamente, sabem ser absurdas?" (PAHL, 1997, p. 9). Essa citação denota a percepção desse autor da existência de uma significação individual que difere dos significados presentes no senso comum. Aventamos, então, a hipótese de que essa divergência dos sentidos do termo seria 
Atitudes e crenças relacionadas ao sucesso em diferentes gerações...

um dos fatores contribuintes para a promoção de uma confusão psíquica e para o aumento da ansiedade e depressão nos dias atuais. Esse aumento da ansiedade e da depressão, por sua vez, pode vir a reforçar a necessidade de sucesso como sinônimo de felicidade, o que traria mais problemas do que soluções, principalmente se essa felicidade for buscada nos prazeres mais primais sem um propósito consistente. Esses comportamentos, associados a uma cobrança constante de sentir emoções positivas idealizadas, reforçam e fecham o círculo vicioso.

A falta de flexibilidade cognitiva para ajustar a noção de sucesso a algo mais real e plausível contribui para o desencadeamento de sofrimento psíquico. A capacidade de flexibilizar o significado de sucesso e criar um autoconceito que se encaixe na realidade individual gera bem-estar e equilíbrio. Além disso, reforçar e priorizar as boas relações familiares e sociais, assim como dar sentido às ações, à vida, e até mesmo aprender a valorizar e validar o sofrimento são estratégias de resiliência necessárias numa época de falta de tempo, ansiedade e impaciência. Torna-se urgente, portanto, para o bem-estar e a saúde psíquica, difundir junto do público esse significado de sucesso mais flexível. Certas considerações feitas por diversos autores recentes citados ao longo deste trabalho coincidem com alguns dos nossos resultados, como os de que, atualmente, o dinheiro não é o objetivo principal para se considerar bem-sucedido. Estes resultados levam-nos a concluir que o sucesso não tem uma medida objetiva estipulada pela sociedade como aparentava, sendo, na realidade, um termo subjetivo que se refere, em geral, à capacidade de consecução de metas reforçadas por motivos pessoais, pela influência de terceiros, família, amigos, trabalho ou mídia. Tais metas individuais podem se referir à família, a relacionamentos, ao lazer, à saúde, à felicidade, ao trabalho, ao dinheiro, à fama, à superação, ao sentido de vida e a quaisquer outras coisas que se possa almejar e consequentemente alcançar.

Assim, desde que haja metas, todos estariam sujeitos a julgamentos pessoais e externos sobre o sucesso e o fracasso, de acordo com aquilo que se espera. Essa subjetividade do termo, portanto, assim como a dicotomia existente entre os significados de sucesso amplamente estimulados na mídia, relacionados com ideias de enriquecimento, fama, poder, excelência e resultados e o significado pessoal mais ligado à felicidade, família, bem-estar, realização e fazer algo que tenha sentido, contribuem para o conflito psicológico e o adoecer, consequentemente. 
Apoiados no trabalho de Pahl (1997), podemos conceber a existência de uma ansiedade do status, que, de acordo com este autor, seria gerada pela dificuldade de medir ou avaliar o sucesso, tendo em conta que as avaliações pessoais e sociais do sucesso podem apresentar medidas diferentes, que não podem ser comparadas quando ele se torna sinônimo de felicidade, outro constructo subjetivo discutido anteriormente.

É importante frisar a necessidade de discussão do conceito, assim como tem sido feito com o termo felicidade, uma vez que um caminho mais saudável se faz necessário. Aventamos que uma boa proposta esteja presente na teoria do "BemEstar" desenvolvida por Seligman (2011). Emoção positiva, engajamento, sentido, relacionamentos positivos e realização são os cinco elementos a serem desenvolvidos, a fim de se atingir o "Bem-Estar", e se compararmos com os nossos três grupos de significados encontrados, podemos concluir que esses itens se assemelham ao resultado alcançado no grupo Equilíbrio, que se apresentou como uma junção dos outros dois grupos, Afetividade/Estar-bem e Capacidade/ Desempenho. Transformar a "meta de resultado" em "meta de processo" pode ser a pedra filosofal. Perseguir dinheiro, poder e status não garante propósito e aprendizado, pois pode trazer prazer fugaz, muitas vezes confundido com felicidade.

A mudança da hipervalorização de metas sociais para metas individuais poderia ser de grande suporte, uma vez que podemos controlar os nossos comportamentos, atitudes e decisões, mas não podemos controlar a resposta, tão pouco a expectativa, dos outros sobre nós: "Assim, a formação para a autonomia do indivíduo representa elemento importante na constituição de possibilidades de usufruir de suas habilidades para solucionar problemas, quebrar paradigmas, melhorar o convívio social”. (GADOTTI, 2003 apud VIEIRA; SILVA, 2019). A expectativa social influencia as decisões, emoções e comportamentos, direcionando as pessoas a perseguirem metas muitas vezes não desejadas por si. O rompimento desse automatismo é necessário para a autonomia, independência, engajamento, desenvolvimento e bem-estar. Educar e capacitar pessoas e ajudá-las a desenvolver inteligência emocional e flexibilização cognitiva é muito importante e convém lembrar que a BNCC (Base Nacional Comum Curricular) já reconhece a importância das competências socioemocionais como um "fator de proteção à saúde mental" (site da BNCC), e por isso já incluiu as 10 competências gerais no currículo escolar nacional. 
Se aliássemos a essas competências uma educação para o sucesso, capacitando pais e professores, no setor educacional, e gestores e empreendedores, no setor empresarial, para uma ressignificação do termo, seria possível alcançarmos um resultado mais assertivo, tanto para o bem-estar pessoal, como para a sociedade como um todo. Mostrar e reforçar a valia das metas individuais aliadas a um propósito e valores será fundamental para a motivação na execução e consequente sensação de realização.

Para que essa transformação aconteça, segundo Adams, (2010, p. 24) apud Vieira; Silva (2019) "a prática educativa deve aproximar à vida concreta do serhumano-ser-de-relações, isto é, um sujeito social e historicamente situado. Trata-se de buscar uma interação entre real e ideal, comprometida com a construção do futuro, mas ancorada no presente."

A pesquisa realizada possibilitou o levantamento de muitas informações relevantes que merecem um estudo mais aprofundado no futuro. Existe, portanto, uma dissonância entre o que as pessoas realmente almejam para si e o que a mídia, as empresas e outros setores da sociedade incentivam e estimulam. Essa divergência, aliada a um distanciamento dos valores internos, éticos e morais, pode transformar-se em fonte de sofrimento, ao fazer com que muitas pessoas persigam a ideia de sucesso difundida e promovida no contexto em que vivem sem compreenderem que essa ideia não está em conformidade com a sua individualidade e com o significado do sucesso real pessoal. Isso pode contribuir para uma crise psicológica e o consequente adoecer, gerados por um conflito existencial e de objetivos. Ressignificar o sucesso torna-se, portanto, urgente para o bem-estar pessoal e social. Reforçar o autoconhecimento para promover um encontro com as necessidades internas mais realistas, construídas sob um foco mais feminino, flexível, pautado pela ética, valores e propósito, aliadas a emoções positivas, pode ser, portanto, uma boa alternativa para as novas formas de trabalho e para o bem-estar psicológico, uma vez que o sucesso institucionalizado, objetivo, externo, não atende adequadamente às demandas pessoais e das empresas. 


\section{REFERÊNCIAS}

ABELE, A. E. \& SPURK, D. How do objective and subjective career success interrelate over time? Journal of Occupational and Organizational Psychology, 2009, p. 82 e p. 803-824.

ARRUDA, A. Teoria das representações sociais e teorias de gênero. Cadernos de Pesquisa, $\mathrm{n}^{\circ} 117,2002$, p. 127-147.

BECK, A. T., RUSH, A. J., SHAW, B. F., \& EMERY, G. Terapia cognitiva da depressão. Porto Alegre: Artmed, 1997.

BECK, J. Terapia Cognitiva: Teoria e prática. Porto Alegre: Artmed, 1997.

BEN-SHAHAR, T. Seja mais feliz: aprenda a viver nas pequenas coisas para uma satisfação permanente. São Paulo: Academia, 2018.

BERGER, P. \& LUCKMAN, T. A construção social da realidade. Petrópolis: Vozes, 1985.

BNCC. Base Nacional Comum Curricular. Disponível em:

http://basenacionalcomum.mec.gov.br/implementacao/praticas/caderno-depraticas/aprofundamentos/195-competencias-socioemocionais-como-fator-deprotecao-a-saude-mental-e-ao-bullying. Acesso em: 7 de outubro de 2020.

CALLANAN, G. A. What price career success? Career Development International, vol. 8, no. 3, p. 126-133, 2003. Disponível em:

http//dx.doi.org/10.1108/13620430310471032. Acesso em: março/2017.

COBRA JR., N. O músculo da alma: A chave para a sabedoria corporal. $2^{\underline{a}}$ ed. rev. Curitiba: Voo. 2017.

DE VRIES, M. F. R. K. The many colors of success: What do executives want out of life? Organizacional Dynamics, vol. 39, no. 1, p. 1-12, 2010.

DIAS, C. L., COLOMBO, T. F. S, MORAIS, A. Ensino e aprendizagem e sua interface com o clima escolar: percepções de alunos e professores do Ensino Fundamental e Médio. Cad. Pesq., São Luís, v. 26, n. 3, p. 265-284, jul./set., 2019. Disponível em: http://dx.doi.org/10.18764/2178-2229.v26n3p265-284. Acesso em: 18 out. 2020

FERRAGE, V. Z. C. Espiritualidade e comportamentos de cidadania organizacional. Expressões de cidadania nas organizações: Um estudo de caso. Orientador: Hermano Carmo. 2012, 147 f. Tese (Mestrado em Relações Interculturais). Universidade Aberta, Lisboa, Portugal, 2012.

GEROLIMATOS, B. \& WORTHING, M. L. Models of success and satisfaction: An interactive, intergerational discussion. Annals of the New York Academy of Sciences, 869, p. 133-139, 1999. 
ITUASSU, C. T. \& TONELLI, M. J. Notas sobre o conceito de sucesso: Sentidos e possíveis (re)significações. RAM. Revista de Administração Mackenzie, vol. 13, nํ. 6, 2012. Disponível em:

http://www.scielo.br/scielo.php?script=sci_arttext\&pid=S1678-69712012000600009, acesso em março/2017.

ITUASSU, C. T. O Sentido do Sucesso: Uma construção social made in USA. Orientador: Maria José Tonelli. Tese em Estudos Organizacionais. Escola de Administração de Empresas. Fundação Getúlio Vargas, São Paulo, Brasil, 2012. Disponível em:

http://bibliotecadigital.fgv.br/dspace/bitstream/handle/10438/9454/TESE\%20VERSA O\%2 0FINALISSIMA.pdf?sequence=1\&isAllowed=y, acesso em março/2017.

JODELET, D. Representações sociais: Um domínio em expansão. In: JODELET, D. (org.). As representações sociais, p. 17-44. Rio de Janeiro: EDUERJ, 2001.

KUIPER, N. A. Depression and causal attributions for Success and failure. Journal of Personality and Social Psychology, vol. 36, n. 3, p. 236-246, 1978.

MACKEY, J. \& SISODIA, R. Capitalismo Consciente: Como libertar o espírito heroico dos negócios. Rio de Janeiro: Alta Books Editora, 2018.

MELLO, R. B. P. F. Atitudes e crenças relacionadas ao sucesso em diferentes gerações: perspectivas intergeracional e intercultural. Orientador: Natália Ramos. Tese: Mestrado em Relações Interculturais. Universidade Aberta. Lisboa, Portugal, 2017.

MOSCOVICI, S. Representações sociais: Investigações em psicologia social. 11 a ed. Petrópolis: Vozes, 2017.

PAHL, R. Depois do sucesso: Ansiedade e identidade fin-de-siècle. São Paulo: Fundação Editora da UNESP, 1997.

RAMOS, N. Interculturalidade(s) e Mobilidade(s) no espaço europeu: viver e comunicar entre culturas. In: The Overarching Issues of the European Space, p. 343-360. Porto: Faculdade de Letras, Universidade do Porto, 2013. https://ler.letras.up.pt/uploads/ficheiros/12349.pdf

RAMOS, N. Tecnologias digitais de informação e comunicação, interculturalidade e formação docente. In: EDAPECI - Revista de Educação a Distância, Práticas Educativas, Comunicacionais e Interculturais. Aracaju, UFS, 16 (1), p.9-30, 2016. http://www.seer.ufs.br/index.php/edapeci/article/view/5206/pdf_2

SALKOVSKIS, P. M. Terapia cognitiva e Aaron T. Beck. In: P. M. SALKOVSKIS. Ed. Fronteiras da terapia cognitiva, p. 455-460. São Paulo: Casa do Psicólogo, 2005.

SELIGMAN, M. E. P. Aprenda a ser otimista. $4^{a}$ ed. Rio de Janeiro: Nova Era, 2012.

SELIGMAN, M. E. P. Florescer: Uma nova compreensão sobre a natureza da felicidade e do bem-estar. Rio de Janeiro: Objetiva, 2011. 
STURGES, J. What it means to succeed: Personal conceptions of career success held by male and female managers at different ages. Ph.D. thesis. School of Management, Cranfield University, UK, 1996.

VIEIRA, E. T.; SILVA, L. S. Economia solidária possibilidade de prática educativa no PROEJA/IFPI. Cad. Pesq., São Luís, v. 26, n. 2, p. 129-150, abr./jun., 2019.

Disponível em: http://dx.doi.org/10.18764/2178-2229.v26n2p129-150. Acesso em: 18 out. 2020.

WAKEFIELD, R. L. Interdisciplinary theoretical foundations for international Public Relations. In: H. M. CULBERTSON \& CHEN NI. International public relations: A comparative analysis. Mahwah: Lawrence Erlbaum Association, 1996.

WELLS, A. Emotional disorders and metacognition: Innovative cognitive therapy. Chichester: John Wiley \& Sons, 2001.

WORLD HEALTH ORGANIZATION. Depression and other common mental disorders: global health estimates. Geneva: WHO, 2017.

Nota: Agradecemos a colaboração de Daiana Zanandrais Cunha 